University of Pennsylvania Carey Law School

Penn Law: Legal Scholarship Repository

Faculty Scholarship at Penn Law

$1-1-2010$

\title{
Presidential Power in Historical Perspective: Reflections' on Calabresi and Yoo's The Unitary Executive
}

Christopher S. Yoo

University of Pennsylvania Carey Law School

Follow this and additional works at: https://scholarship.law.upenn.edu/faculty_scholarship

Part of the American Politics Commons, Constitutional Law Commons, Legal History Commons, Models and Methods Commons, President/Executive Department Commons, and the Public

Administration Commons

\section{Repository Citation}

Yoo, Christopher S., "Presidential Power in Historical Perspective: Reflections' on Calabresi and Yoo's The Unitary Executive" (2010). Faculty Scholarship at Penn Law. 359.

https://scholarship.law.upenn.edu/faculty_scholarship/359

This Article is brought to you for free and open access by Penn Law: Legal Scholarship Repository. It has been accepted for inclusion in Faculty Scholarship at Penn Law by an authorized administrator of Penn Law: Legal Scholarship Repository. For more information, please contact PennlawIR@law.upenn.edu. 


\title{
SYMPOSIUM: \\ PRESIDENTIAL POWER IN HISTORICAL PERSPECTIVE: REFLECTIONS ON CALABRESI AND YOO'S THE UNITARY EXECUTIVE
}

\section{FOREWORD}

\author{
Christopher S. Yoo*
}

\section{INTRODUCTION}

On February 6 and 7, 2009, more than three dozen of the nation's most distinguished commentators on presidential power gathered in Philadelphia to explore themes raised by the book that Steven Calabresi and I co-authored reviewing the history of presidential practices with respect to the unitary executive. ${ }^{1}$ We are honored and humbled that so many friends and colleagues, both those sympathetic to our argument and those who disagree with some or all of our analysis, joined here together to celebrate our book's publication and to debate its merits. Publication of a book is always a major milestone in any scholar's professional life, and this book is no exception. The conference honoring our book and this special journal issue bringing together the articles presented there provide me with a welcome opportunity both to look backwards on the history of our project and to look forwards at the questions yet to be answered.

\section{LOOKING BACKWARD}

We first presented the research that eventually became this book at the Symposium on "Presidential Power in the 21st Century" hosted by the Case Western Reserve University School of Law in April 1997. In addition to representing the public debut of this project, this symposium also marked the beginning of a number of friendships that would prove enduring. Our host was Michael Gerhardt, who was then Case Western's Dean and who graciously agreed to participate in this conference. The conference speakers included many of the

Professor of Law, University of Pennsylvania Law School.

1 Steven G. Calabresi \& Christopher S. Yoo, The Unitary executive: Presidential POWER FROM WASHINGTON TO BUSH (2008). 
people here today, including Michael Fitts, who unbeknownst to me at the time would eventually become my Dean and the host of this conference.

It is hard to capture how controversial our research was when we first presented it at that conference in 1997. At the time, the unitary executive was widely criticized as an invention of the Reagan Administration that was inconsistent with our nation's practices and traditions. $^{2}$ In addition, institutions like the independent counsels enjoyed widespread political support, particularly since the Whitewater investigation had not yet shifted its focus from allegations of financial wrongdoing to the sordid details of the nature of President Bill Clinton's relationship with Monica Lewinsky. Indeed, twelve years ago our prediction that the law would repudiate the Ethics in Government Act (EIGA) in much the same manner as it repudiated the Tenure of Office Act seemed quite radical. ${ }^{3}$

Looking back, I cannot help but be struck by how much perceptions have changed over the past dozen years. The Whitewater investigation demonstrated that independent counsel investigations did not restrict their attention to any particular party and demonstrated the accuracy of Justice Scalia's admonitions about the dangers of prosecutorial discretion unchecked by presidential oversight. ${ }^{4}$ Political support for the EIGA abruptly vanished, and the statute was allowed to sunset out of existence. In addition, as Elena Kagan has documented, the shift from Republican to Democratic control of the White House during the Clinton years did not cause any decline in the president's support for centralized control of the administration. ${ }^{5}$ The early indications are that the Obama Administration is as committed to presidential control of the execution of the law as his pre-

2 See, e.g., Lawrence Lessig \& Cass R. Sunstein, The President and the Administration, 94 Colum. L. REv. 1, 5-6 (1994) (arguing that by the late 1970s, the scope of presidential authority over the execution of the law before "President Reagan's efforts to assert hierarchical control over the bureaucracy" spurred "a minor revolution"); Morton Rosenberg, Congress's Prerogative over Agencies and Agency Decisionmakers: The Rise and Demise of the Reagan Administration's Theory of the Unitary Executive, 57 GEO. WASH. L. REV. 627, 634 (1989) (calling the unitary executive "a myth concocted by the Reagan administration to provide a semblance of legal respectability for an aggressive administrative strategy designed to accomplish what its failed legislative agenda could not"). For a modern restatement of this position, see Mark Tushnet, A Political Perspective on the Theory of the Unitary Executive, 12 U. PA. J. ConsT. L. 313, 314, 318-23 (2010) (distinguishing a "strong theory" of the unitary executive emerging under the Reagan administration).

3 See Steven G. Calabresi \& Christopher S. Yoo, The Unitary Executive During the First HalfCentury, 47 CASE W. RES. L. REV. 1451, 1462 (1997).

4 See Morrison v. Olson, 487 U.S. 654, 727-32 (1988) (Scalia, J., dissenting).

5 Elena Kagan, Presidential Administration, 114 HARv. L. Rev. 2245 (2001). 
decessors, if not more so. ${ }^{6}$ The consistency with which the last several administrations have embraced centralized control over the administration of federal law eloquently demonstrates how the unitary executive has gained general acceptance. ${ }^{7}$ It also reflects a recognition that debates over the unitary executive are not merely a matter of partisanship, as some have claimed, but rather raise fundamental issues about the proper balance of power within the federal government that transcend the politics of the moment.

One major focus of our project is to debunk the notion that the unitary executive is a recent invention. ${ }^{8}$ As our book documents, the debate over the president's authority over the execution of the law was one of the major issues debated by the First Congress ${ }^{9}$ and has lain at the heart of some of the biggest political controversies in U.S. history. Perhaps the most critical moment in our nation's history was the period following the Civil War, which pitted a White House that wanted a quick, conciliatory reunification of our nation against a Congress that wanted a more punitive Reconstruction. A president who was elected by one party was succeeded by a vice president from the opposition party who had been added to the ticket to broaden its appeal. Furthermore, Abraham Lincoln's unique strength of leadership played a critical role in holding the nation together when confronted with perhaps its greatest crisis. Sadly, his successor, Andrew Johnson, lacked Lincoln's political skills. The result was the first presidential impeachment in our nation's history. The grounds for the impeachment centered on the unitary executive, specifically the propriety of Johnson's removal of Secretary of War Edwin Stanton despite the enactment of the Tenure of Office Act, which ostensibly denied him the power to do so. ${ }^{10}$

Another salient example is Watergate, which represented perhaps the greatest challenge in our nation's history to people's faith in the government. Most importantly for the purposes of our book, the Nixon Administration's removal of Archibald Cox as special prosecu-

6 See Cary Coglianese, Presidential Control of Administrative Agencies: A Debate over Law or Politics?, 12 U. PA. J. ConsT. L. 637, 638-41 (2010).

7 See Cynthia R. Farina, False Comfort and Impossible Promises: Uncertainty, Information Overload, and the Unitary Executive, 12 U. PA. J. CONST. L. 357, 359 (2010) (noting how the unitary executive "has attained mainstream constitutional status and won adherents across the political spectrum").

8 See CALABRESI \& YOO, supra note 1, at 3 (calling the controversy over the unitary executive "The Oldest Debate in Constitutional Law"); see also Lessig \& Sunstein, supra note 2, at 5 (calling the controversy over the unitary executive "[a]n Old (But Quite Lively) Debate").

9 CALABRESI \& YOO, supra note 1, at 35-36.

$10 \quad I d$. at $179-87$. 
tor set the stage for a twenty-one year experiment with independent counsels appointed under the EIGA. The widespread use of independent counsels plagued every administration that followed and led to the near impeachment of one president (Richard Nixon) and the actual impeachment of another (Bill Clinton). ${ }^{11}$

Other examples that we discuss at length are less well known, but no less important. Consider Andrew Jackson's war on the Bank of the United States. After Jackson vetoed the bill that would have reauthorized the Bank, the Bank, under the leadership of Nicholas Biddle, actively campaigned against Jackson and precipitated a financial panic to increase the political pressure on Jackson. To get a sense of the magnitude of the controversy, one need only imagine what would happen if the Federal Reserve Bank and its Chairman actively campaigned against a particular candidate in an election. After winning the election, Jackson exerted all of the means at his disposal to crush the Bank, including the statutory authority to revoke the Bank's authority to serve as the official repository for federal funds. After Treasury Secretary William Duane refused to remove the federal deposits, Jackson fired him and replaced him with Roger Taney, who acceded to Jackson's wishes. This touched off the biggest political battle the country had ever witnessed up to that point. Its final resolution is widely regarded as a ringing reaffirmation of the unitariness of the executive branch. ${ }^{12}$

In addition, more or less contemporaneously with his plan to pack the Supreme Court, Franklin Delano Roosevelt attempted to reorganize the executive branch to bring it firmly within presidential control. Even FDR's enormous popularity was not enough to carry the day. ${ }^{13}$

We recount these and other stories at length in our book. These historical episodes help us place the recent controversy over the scope of executive authority asserted by President George W. Bush in its proper perspective. Most importantly, the episodes we recount underscore that the importance of keeping the deliberations over the unitary executive from becoming overwhelmed by the politics of the moment. The implications are ultimately more important and enduring.

\footnotetext{
11 Id. at 353-54, 365-66, 376-78, 386, 390, 400-04, 425-27.

12 Id. at $105-19$.

13 Id. at 291-99.
} 


\section{LOOKING FORWARD}

If someone had told me that the project would still be incomplete after more than a dozen years of work, I would not have believed them. But, as anyone who has written a book can attest, the process of learning and refining that underlies any extended program of research is perpetually inchoate. As part of this process, I am grateful to all of the participants in this conference for the willingness to devote their time and intellect to engage our work in such a perceptive and meaningful way.

During the course of this conference, we received a wealth of new insights, ideas, comments, and criticisms that we will clearly explore in greater depth in our later work. Rather than using the limited space available in this issue to respond to every issue raised during the conference, I will limit myself to a few broad observations about some of the larger themes that recurred in the commentary.

\section{A. The Widespread Acceptance of Departmentalism}

One of the most striking aspects of this conference is the general acceptance of departmentalism as the appropriate approach to constitutional interpretation. Some participants openly embrace threebranch constitutional interpretation in their submissions, ${ }^{14}$ while others endorse or at least express sympathy with the approach in their other published work. ${ }^{15}$

I find the growing acceptance of departmentalism as an interpretive methodology to be both reassuring and frustrating. On the one hand, the body of scholarship rejecting judicial supremacy and acknowledging the Congress's and the president's authority to interpret the Constitution grows larger with every passing year. ${ }^{16}$ And yet despite the near absence of any scholarly defenses of judicial supremacy, ${ }^{17}$ most practicing lawyers unquestioningly accept judical suprem-

14 See Michael J. Gerhardt, Constitutional Construction and Departmentalism: A Case Study of the Demise of the Whig Presidency, 12 U. PA. J. Const. L. 425, 427-31 (2010); L.A. Powe, Jr., The Court's Constitution, 12 U. PA. J. CONST. L. 529, 529 (2010) ("Departmentalism—the ability and right of each branch of the federal government to interpret the Constitution for itself-has a long and often honorable history.").

15 See Neal Devins \& Louis Fisher, Essay, Judicial Exclusivity and Political Instability, 84 VA. L. REv. 83 (1998); Mark Tushnet, Alternative Forms of Judicial Review, 101 MICH. L. REV. 2781 (2003).

16 See CALABResi \& Yoo, supra note 1, at 436 n.5 (collecting authorities); Calabresi \& Yoo, supra note 3 , at 1463-72 (same).

17 For the leading recent defense of judicial supremacy, see Larry Alexander \& Frederick Schauer, On Extrajudicial Constitutional Interpretation, 110 HARV. L. REV. 1359 (1997). 
acy as the definitive approach to constitutional interpretation. The disconnect between the scholarly consensus and the conventional wisdom remains something of a puzzle.

\section{B. Removal Versus Direction}

Several commentators have observed that our book offers a stronger showing of presidential assertions of the power to remove executive officials and a weaker showing of the president's authority to direct executive officials in their actions. ${ }^{18}$ Some dispute the historical origins of the practice. ${ }^{19}$ Others dispute whether the power of direction has been borne out over time. ${ }^{20}$

As we note in our book, the tradition of presidential direction of subordinates remains quite strong, exemplified in the executive orders mandating nondiscrimination in hiring and in federal contracts and establishing centralized review of all agency rulemaking. ${ }^{21}$ And throughout U.S. history, presidents continued to issue policy directives to subordinate federal officials, including members of the independent regulatory commissions.

Perhaps the most dramatic recent example is Clinton's practice of issuing directives ordering agencies to initiate specific regulatory actions and even dictating the outcome, a development that we discuss, but to which we probably do not pay sufficient attention. ${ }^{22}$ The result is a form of "presidential administration" in which the President ex-

18 See Richard J. Pierce, Jr., Saving the Unitary Executive Theory from Those Who Would Distort and Abuse It: A Review of The Unitary Executive by Steven G. Calabresi and Christopher S. Yoo, 12 U. PA. J. CONST. L. 593, 597-99 (2010). For the leading statement of this position, see Peter L. Strauss, Overseer, or "The Decider"? The President in Administrative Law, 75 GEO. WASH. L. REV. 696 (2007).

19 Jerry Mashaw recounts the episode during the Embargo in which President Jefferson instructed the collectors of the revenue to hold a vessel. The courts held that nothing in the statute gave the president the authority to direct the collectors to hold vessels contrary to their judgment. Jefferson instructed other collectors to ignore mandamus orders to that effect. Jerry L. Mashaw, Center and Periphery in Antebellum Federal Administration: The Multiple Faces of Popular Control, 12 U. PA. J. CONST. L. 331, 336-39 (2010) [hereinafter Mashaw, Center and Periphery]. Although Mashaw focuses on the judicial interpretation of the statute to conclude that Congress has the power to insulate decisions made by subordinate executive officials from presidential interference, focusing on Jefferson's determination to ignore such a judicial construction supports the opposite conclusion. See Jerry L. Mashaw, Governmental Practice and Presidential Direction: Lessons from the Antebellum Republic?, 45 WiLlameTte L. REV. 659, 677-80 (2009) (entertaining but ultimately rejecting alternative interpretations of this episode).

20 See Harold J. Krent, The Sometimes Unitary Executive: Presidential Practice Throughout History, 25 CONST. COMment. 489, 492 (2009) (reviewing CALABRESI \& Yoo, supra note 1).

21 CALABRESI \& YoO, supra note 1, at 420-22.

22 Id. at 395. For a more complete discussion, see Kagan, supra note 5, at 2290-303. 
erts far more direct influence over regulatory policy than the ex post review conducted by the Office of Management and Budget traditionally associated with the unitary executive. ${ }^{23}$ The Administration of George W. Bush expanded the practice to include "prompt letters" requesting that particular regulatory initiatives be undertaken, as has the Obama Administration. ${ }^{24}$

Making the president's policy preferences clear before the issue has crystallized into concrete regulatory action allows the president to influence the course of administration at the time when decisionmaking processes are the most open and malleable. It also effectively avoids the political liabilities of having to remove an official or overturn a decision after it has been made. Thus, if anything, we see the tradition of presidential direction of lower executive officials as growing stronger, not weaker. And even if this criticism is well taken, these arguments concede that our book does establish the strength of the tradition in favor of the president's authority to remove. In so doing, they confirm the essential point of the unitary executive position.

\section{The Lack of Actual Control over Agency Officials}

A number of commentators observe that it is impossible for any one person to exercise control over a bureaucracy as large as the federal government's. ${ }^{25}$ In such a world, a unitary executive, in which the president exercises meaningful control over all aspects of the administration, remains a practical impossibility.

In my opinion, this argument cuts in the other direction. The fact that presidents cannot exercise de facto authority over all aspects of the execution of federal law strengthens rather than weakens the case for recognizing that they possess strong de jure authority. Consider the same set of arguments in the context of any large corporation characterized by strong, hierarchical control. Even though the chief executive officer cannot oversee all of the myriad tasks undertaken by the company in any meaningful way, this fact does not prevent such an organization from functioning in a reasonably coherent manner. The reason is that any actor in the organization who persistently fails

23 See Tushnet, supra note 2, at 325-29.

24 Harold H. Bruff, Presidential Power Meets Bureaucratic Expertise, 12 U. PA. J. CONST. L. 461, 486-87 (2010) (citing John D. Graham, Saving Lives Through Administrative Law and Economics, 157 U. PA. L. REV. 395, 460 (2008)).

25 See id. at 482-84, 488; Farina, supra note 7, at 422; Douglas H. Ginsburg \& Steven Menashi, Nondelegation and the Unitary Executive, 12 U. PA. J. CONST. L. 251, 265 (2010); Pierce, supra note 18, at 601-02. 
to carry out his or her duties in an appropriate manner face having his or her decisions overridden and eventually dismissed. The fact that this degree of oversight cannot be exercised every time a subordinate makes a mistake does not weaken the importance of ensuring that the CEO possesses the authority to intervene whenever necessary. Indeed, it is the constancy of that threat that makes up for the CEO's inability to police every employee's conduct.

\section{The Role of Politics}

Finally, a number of commentators observe that the normative attractiveness of the unitary executive must be evaluated in light of a wide range of political considerations that may or may not make strong unitary control more likely to lead to good policy outcomes. ${ }^{26}$ Jerry Mashaw points out that alternative mechanisms exist by which citizens can exercise popular control of administration. ${ }^{27}$

As Bill Marshall notes, certain types of structural purists would regard the normative implications as being irrelevant. ${ }^{28}$ Furthermore, ensuring that administrative policy reflects majority preferences is only one of several normative justifications for unitariness. Other considerations include energy, accountability, and relative lack of susceptibility to collective action problems, just to name a few. ${ }^{29}$ Even if one is willing to take such considerations into account, the arguments advanced so far simply demonstrate the possibility that the president may be less representative of majority preferences than Congress; they do little to establish the whether such an outcome is likely.

Consider, for example, Professor Nzelibe's observation that a successful president need only capture a bare majority of the voters in states constituting a bare majority of the Electoral College. Thus as a theoretical matter, a president could gain election despite having the support of little more than twenty-five percent of the nation's voters (fifty percent of the voters in states comprising fifty percent of the electorate) and the support of as few as eleven states (the minimum

See Farina, supra note 7, at 374-95; William P. Marshall, The Vision of the Nationalist Presidency or Another Unpersuasive Claim for Expansive Presidential Power, 12 U. PA. J. CONST. L. 549, 550-66 (2010); Jide Nzelibe, Does the Unitary Presidency Really Need a Nationalist Justification?, 12 U. PA. J. CONST. L. 623, 625-28 (2010); Tushnet, supra note 2, at 315-18, 32225.

27 Mashaw, Center and Periphery, supra note 19, at 332-34.

28 Marshall, supra note 26, at 556.

29 Steven G. Calabresi \& Christopher S. Yoo, Remove Morrison v. Olson, 62 VAND. L. Rev. EN BANC 103, 116 (2009), http://www.vanderbilt.edu/lawreview/articles/2009/11/ Calabresi-Yoo-62-Vand-L-Rev-En-Banc-103.pdf. 
number of states needed to command a majority of the Electoral College). ${ }^{30}$ The same is true of the House of Representatives, which can be controlled by a bare majority of the electors for a bare majority of the 435 districts, which again may theoretically amount to no more than twenty-five percent of the nation's voters. This means that, as with the president, the median Representative may also reflect the views of no more than twenty-five percent of the nation. Indeed, to the extent that congressional politics are polarized, a large diffuse majority may find it particularly hard to attract proportionate representation in the House. The situation is even more problematic in the Senate, where representation is not based on population. Since the twenty-five least populous states encompass only sixteen percent of the nation's population, ${ }^{31}$ the median voter in the Senate could reflect the views of as little as eight percent of the population.

Determining whether Congress or the presidency is more likely to be representative of the preferences of the overall electorate depends on which outcome is likely to be more robust. This is not a question that can be answered a priori based on theoretical arguments. Given the nature of presidential elections, it is quite plausible that the chief executive is more likely than Congress to reflect the views of a diffuse national majority.

It is equally important to analyze which actors would fill the void should the administration be screened from presidential control. As we have noted elsewhere, preventing the president from exercising control over the bureaucracy simply renders the bureaucracy completely subject to a single branch of the government: Congress. Thus, contrary to what some have suggested, ensuring the president's continuing role in overseeing the execution of the law helps preserve the type of dynamic tension among the branches that James Madison envisioned. Deviating from it would leave the administration to the mercy of a single branch. ${ }^{32}$

\section{CONCLUSION}

Like any fertile subject of legal and historical analysis, the debate over the proper scope of the president's authority over the execution of the law is one that may never be fully resolved. This conference,

\footnotetext{
30 See Nzelibe, supra note 26, at 626; see also Marshall, supra note 26, at 553-55.

31 U.S. Census Bur., National and State Population Estimates: Annual Population Estimates 2000 to 2009, http://www.census.gov/popest/states/NST-ann-est.html (last visited Jan. 29, 2010).

32 See Calabresi \& Yoo, supra note 29, at 117.
} 
which was originally intended to mark the end of our book project, is much like the conference that marked its beginning, providing more questions than answers and serving as a basis for debating a wide range of interesting and controversial issues. We offer our deepest thanks to everyone who participated in the conference and look forward to continuing the debate in the years to come. 